\title{
The Hidden Conflicts with an Unorthodox Translator: Dora Gabe's Contributions to the Jewish Press in Bulgaria
}

\begin{abstract}
The article presents the contributions of Dora Gabe to the Jewish newspaper Maccabi, published in Sofia from 1920 to 1940. She cooperated with the paper both as a translator and an original author. Gabe's texts in Maccabi have not been reprinted and are almost forgotten. This factor explains why they need to be revisited. First, I trace Edmond Fleg's influence on Gabe's ideas on Jewish identity, as the poet is a vivid promoter and a keen translator of Fleg's work. Then this topic is represented in light of a hidden conflict between other journalists from Maccabi circles and Dora Gabe. The main argument of the text is that Gabe was criticized not only for assimilating into Bulgarian society but mostly because of her feminist ideas and her original, paradoxically anti-national viewpoints on the Zionist movement.
\end{abstract}

Keywords: interwar period in Bulgarian literature, history of translation, Jewish press, Zionist movement in Bulgaria, Dora Gabe, Edmond Fleg.

In a paper, broad in scope and dedicated to the question of defining whether there is French-language Jewish literature or Jewish literature written in France, Clara Lévy discusses the process of breaking from the criteria based on which journalists, literary critics, and scholars try to identify and characterize this phenomenon. ${ }^{1}$ Four primary characteristics are necessary for including an author or work within the framework of French-language Jewish literature: the author's ethnic/religious descent, the language employed, the topics touched upon, and the presence of specifically Jewish matters. Lévy, however, shows how none of these principles

${ }^{1}$ Clara Lévy, Cherry Schecker, "The Controversial Question of 'French Jewish Literature'," Nationalities Papers 40 (2012), 3:395-409. 
is sufficient for defining a writer as a creator of Jewish literature. Even the very debates about the origin of the authors as a criterion for belonging to a group show the difficulties that lie ahead of any attempt at definition. An example is the statement of the editor of the literature section of the journal L'Arche, Vladimir Rabinovich:

Imagine I were to compile a Jewish anthology. Which writers should be included? Those whose origins are established, as is the case in Edmond Fleg's anthology? In this case, Proust would be omitted. Why? He was only half Jewish. Pallière would also be excluded. Why? He was not circumcised. But Simone Weil, yes, she would unquestionably figure. In my opinion, this solution is unsatisfactory. ${ }^{2}$

The literary sociologist traces the process of rejecting the "hard" criteria for belonging to the Jewish literary community as well as considers the potential to replace these criteria by increasingly wide and blurred concepts-such as co-participation in the Jewish fate, a skill to recreate the imaginarium of the ethnic group, or to transfer the contemporary problems and ramblings of French Jews. Lévy's research streams down these issues to focus on processes of identification. She understands these in terms of a sociological phenomenon that defines the belonging of a given author to a "minority" literary field and the consequences for his or her social status. Moreover, the scholar shows the interdependence of different forms of self-identification with Jews and the impossibility of pointing out texts that can be defined as belonging to French-language Jewish literature.

In the body of research dedicated to the Jewishness of Dora Gabe, the question concerning the existence of Bulgarian-written Jewish literature or Jewish literature created in Bulgaria is not raised. It seems to me that if such an issue were to be explored at all, the related discussion would very much look like the debates in France. This resemblance would not be due to political and historical processes in Bulgaria that were similar to those conditioning the place of Jews in French society-they were essentially different. The similarity would be in Jewish self-identification at the end of the nineteenth and the beginning of the twentieth century, which was multi-faceted and multi-compounded in both France and Bulgaria.

Scholars rarely pay attention to the fact that Jewishness can be experienced as a religious, historical, cultural, or national belonging without

${ }^{2}$ Rabi, Lettres juives, domaine français. Quoted in Lévy, Schecker, "The Controversial Question of 'French Jewish Literature'," 396. 
making it necessary for these aspects to overlap. On the contrary, these elements of belonging very often confront each other. In most studies in which Gabe's Jewishness is problematized, her identification is presented as an ethnic origin that comes to mean a biographical fact and a literary motif, seen as a rather insignificant feature for both the wider audience and the literary-historical narrative. "The Jewish descent of the poetsays Katia Kuzmanova-Zografova-is repressed in the consciousness of Bulgarian society ... it is as if forgotten." ${ }^{3}$ It is interesting to note the ways in which the category of ethnic descent is blurred when defining the poet as a Bulgarian writer:

There is no doubt about the descent of the Bulgarian poet Dora Gabe. She is a daughter of Russian Jews who migrated to our lands after the 1884 persecutions of Jews in Russia. How does Gabe herself feel, though? In her creative work she has always belonged to Bulgarian literature, and her poems for children are favorite poems for young Bulgarians, forever anchored in their primers. ${ }^{4}$

Furthermore, the words of Radka Pencheva can be interpreted as exemplifying the concept that belonging to a given national body of literature is equivalent to defining the artist's national belonging. This conviction is complemented by the view that the ethnic descent and nationality of the poet do not define her ways of sensing the world and are rarely problematized in her rich creative work. For Katia Kuzmanova-Zografova, Dora Gabe's religious self-identification has much greater influence: "It feels to me that [her religious self-identification] is the prevailing defining side of Gabe's problematic identities, because the poet is not that much split in terms of her ethnic belonging and could comfortably fit into the definition of a Bulgarian Jew or a Jewish Bulgarian." ${ }^{5}$ Her adoption of Christianity, on the eve of her marriage to Boyan Penev, ${ }^{6}$ is considered a key factor

${ }^{3}$ Katia Kuzmanova-Zografova, "Mnogolikata Dora Gabe: Verskata, etnicheskata i natsionalnata identichnost na poetesata," in Kremena Miteva, Marinela Paskaleva (eds.), 120 godini ot rozhdenieto na Dora Gabe: Yubileen sbornik (Sofia, 2010), 121.

${ }^{4}$ Radka Pencheva, "Dora Gabe i evreystvoto," in Miteva, Paskaleva (eds.), 120 godini ot rozhdenieto na Dora Gabe, 109.

${ }^{5}$ Kuzmanova-Zografova, "Mnogolikata Dora Gabe," 129.

${ }^{6}$ In the Catalogue of Sources about Dora Gabe, in the section on biographical documents, there is information that the Dobrich State Archive stores Dora Gabe's Orthodox Baptism Certificate. It was issued by pastor Vasil Vulchev from the village of Vladimirovo on 29 December 1908. The document is archived in State Archive Dobrich, Fond 236 K, archival description 1, series 37, item 133. See Tonka Ivanova, Katalog na izvori za Dora Gabe (Shumen, 1999), 15. I note this fact because Katia Kuzmanova-Zografova writes in the already cited article that Gabe adopted Christianity on 5 January 1909. Maria Mihail 
by Miglena Nikolchina too. ${ }^{7}$ The act of baptism officially places the poet outside Orthodox Jewish circles and among the Jewish intelligentsia, ${ }^{8}$ for she does not adhere strictly to religious observance but adopts Jewishness as a cultural and historical heritage and a cultural community. Gabe's decision to become a Christian thus had repercussions in Jewish circles.

Thus far, only Radka Pencheva has attempted to reconstruct Gabe's image through the eyes of the Bulgarian Jewish community, uncovering archived materials from Jewish printed sources. ${ }^{9}$ Relatively little is known about the collaboration of the poet with organizations such as the Jewish People University and the publishing series Probuda ${ }^{10}$ or about her participation in prestigious Jewish cultural initiatives such as arranging the memorial exhibition of works by the sculptor Boris Shatz in Sofia. ${ }^{11}$ Little

also refers to an inaccurate information, noting the baptism day down as 15 January 1908. See Kuzmanova-Zografova, "Mnogolikata Dora Gabe," 121; and Maria Mihail, Tazhnite ochi na minaloto: Dora Gabe razkazva (Sofia, 1994), 103.

${ }^{7}$ Miglena Nikolchina, Rodena ot glavata: Fabuli i syuzheti $v$ zhenskata literaturna istoria (Sofia, 2002).

${ }^{8}$ The original definition used by Petar Gabe is "the intelligent part of the Jewish people," employed in his address to the Parliamentarians gathered to discuss the legitimacy of his election as a member of parliament at the end of November 1894. See author's note to the paper: Sami Mayer, "Dora Gabe: Etyud," Maccabi 7 (1932), 13.

9 The materials in question are two valuable articles, published in Maccabi: Ben Avram, "Gorchivata chasha," Maccabi 4 (1931), 5-6; and Mayer, "Dora Gabe: Etyud," 10-13. See Pencheva, "Dora Gabe i evreystvoto," 109-119.

${ }^{10}$ The Probuda Library was a publishing series, launched in 1938. The purpose of the series was to counteract "a policy, which aims, at any price, at using both excusable and inexcusable means, to destroy the Jewishness, to demolish all that speaks favorably about the Jews as a whole, and to deprive the Jews themselves from the opportunity to start living anywhere a relatively calm and free life anew." Among the editions published under its aegis were the opinion poll by Georgi Valkov, Balgarskata obshtestvenost za rasizma $i$ antisemitizma (1938), Ivan Kinkel's study Evreyskata i hristiyanska etika v tyahnoto shodstvo i razlichie ot sotsialno gledishte (1938), Leo Cohen's Evreinat v balgarskata literatura (1939), as well as a range of translated editions. The Library ceased its activity at the end of 1939.

${ }^{11}$ Boris Shatz memorial exhibition was launched in Sofia in "Preslav" Galery in February 1934. Dora Gabe was the only woman who participated in the committee arranging the exhibition. The committee members were also Josef Serper, a chair of the Jewish Ashkenazi community; Eli Basan, a chair of the Jewish Sephardic Municipality; Khaim Farhi, a chair of the Central Consistory of the Jews in Bulgaria; and, in line with them, also representatives of the Association of the Bulgarian Sculptors, the first Shatz's disciples in Bulgaria; representatives of the Academy of Arts and of the Ministry of Public Enlightenment; journalists and painters. See Tatyana Dimitrova, Hudozhnitsi evrei v Bulgaria (Sofia, 2002), 6. Regarding the acquaintance of Theodor Herzl and Boris Shatz see Nurit Shilo-Cohen (ed.), Bezalel 1906-1929: Exhibition Catalogue (Jerusalem, 1983). Tatyana Dimitrova traces the ways in which Boris Shatz applies his teaching experience, generated in the Sofia Arts Academy, in shaping the idea of the Betzalel School of Arts and Crafts in Jerusalem. She concludes that the so-called "Bulgarian style," inspired by Bulgarian folklore and Shatz' 
or almost nothing is known about Gabe's literary contacts with other Jewish artists. ${ }^{12}$ As of yet, attention has not been paid either to the political significance of Gabe's identification after World War II, despite the fact that archived documents showing the attitude of communist authorities to minority groups are, by now, easily accessible. ${ }^{13}$ Without this context it is exceptionally difficult to understand the position of the poet in the literary scene after 9 September $1944 .{ }^{14}$ Put otherwise, the theme of Dora

attempts to create "national Jewish art" have common roots. See Dimitrova, Hudozhnitsi evrei v Bulgaria, 8.

${ }^{12}$ This topic has not been studied systematically so far, although the poet's archives keep traces of her acquaintance with the following writers and artists of Jewish origin from Poland and Russia: Jan Śpiewak, Artur Sandauer, Raul Koczalski, Leonid Lewin and others. The poet's participation in an anthology of Bulgarian Jewish literature is also interesting-information concerning this issue are to be found in Gabe's letters from 1967. See Central State Archives, Fond 1771 K, archival description 1, series 959.

${ }^{13}$ Kostadin Grozev, Rumyana Marinova-Hristidi, Darzhavna sigurnost $i$ evreyskata obshtnost v Bulgaria 1944-1989 g.: Dokumentalen sbornik (Sofia, 2012).

${ }^{14}$ It is important in this context to cite a note from Petar Dinekov's diary dated July 1969: "Lately, another case of literary narrow-mindedness was circulated in the literary circles: the murmur surrounding a poem by Dora Gabe due to two expressions [she uses]: she called herself 'a sister of Jesus' (religiousness!) and stated: 'I am a daughter of two people' (Zionism!). Some foretell that this is going to cost her The Georgi Dimitroff Prize. Last Sunday, Em. Stanev came to my place to read the poem (in issue 6 of Septemvri Journal) he was called on the phone by the highest in rank to ask for his opinion. After the reading he was also impressed that the poem is nice. Disapproval [of the poem] is expressed by the base levels of our thinking only. The first time of hearing that this poem has awakened a murmur was at the sitting of the literary section of the Committee of The Georgi Dimitroff Prize. We were sitting at Dzhagarov's office. When Dora Gabe's turn came, D. Metodiev took the floor and stated that he is not going to vote in favor of her. He backed up this with the poem from the poetic cycle The Letters to No One [Pisma do nikogo]. And he did not vote indeed. Initially, Dzhagarov abstained, but then he raised his hand. At the sitting of the big Committee Metodiev remained silent, but with no doubt, he voted against. I took the floor and spoke in defence of Dora Gabe; the result was a majority. They say the first signal against this poem was issued by Lyubo Georgiev: [when] as an editor of "Bulgarian Writer' he refused to include Dora Gabe's new book [in the plan of the publishing house]" (Bulgarian Historical Archive, Fond 904, series 65, item 12). The ethnic origins of Dora Gabe are thus one of the knotted problems in her complicated and ambiguous inter-relationships with the communist authorities. The poet remained a non-party member of the Union of the Writers but subjected her pen to political conjuncture. She expressed a position on some public issues, criticizing those in power-she signed, for example, the letter to Bertrand Russell and Jean-Paul Sartre, in which the negative role of Bulgaria during the Prague Spring was described. At the same time, however, Gabe benefited from all the privileges and honors of a poet courted by the party. See Vladimir Migev, Balgarskite pisateli i politicheskia zhivot $v$ Bulgaria: 1944-1970 (Sofia, 2001). And in so far as the poem giving rise to murmur in 1969 (the reference is to "Pismo no. 10" from Pisma do nikogo; see Dora Gabe, Prokoba: Stihotvorenia (Sofia, 1994), 16-17) had not been published in volumes of poetry in 1970 (Nevidimi ochi), 1973 (Sgastena tishina), 1976 (Glabini: Razgovori s moreto), and 1982 (Svetat e tayna); the poem Drugoverka appeared in Volume 1 of Izbrani stihove by Dora Gabe, published in 1978 under the title Osinovenata. See Magdalena Shishkova, "Za 
Gabe's Jewishness is not yet fully exhausted; additional systematic studies could surely occur in the future.

My purpose here, however, is not to sketch possible directions for further analysis of Gabe's ethnic origins; the themes outlined above are far from indicate the full spectrum of possible viewpoints on this complex issue. I would like to point, though, to a barely known essay by Gabe and to three forgotten translations that she completed from Russian and French. These texts cast new light on the questions raised thus far regarding how the Bulgarian Jewish community has perceived the poet's social and creative work and the embroiled issues that Dora Gabe herself had with her own ethnicity.

My studies were provoked by an evident contradiction. The poet leaned toward advocating Zionism in her writing and initiatives, and never renounced her Jewish origins, although she converted to Eastern Orthodox Christianity and chose a lifestyle not in accordance with Jewish tradition. The Jewish community accepted Gabe, appreciating her as an author, translator, organizer, and spokeswoman. Without a doubt the place she earned on the Bulgarian literary scene and in Bulgarian cultural life inspired respect. Despite that, publicists from the very same Jewish newspapers in which the poet published did not approve of her assimilation in both her personal life and career, accusing her of treason. Tracing this conflict suggests that mutual lack of understanding, despite the stated readiness for collaboration, is born in a mismatch of the definitions of the aims and essence of the Zionist movement. The poet's views about this topic are original, formed in the first place under the influence of her upbringing and the views of her father Petar Gabe, and later on through her encounters with the French writer, poet, and playwright of Jewish descent Edmond Fleg.

tselta i haraktera na izdanieto," in Dora Gabe, Svetat e tayna: Poezia i proza (Sofia, 1994), 475-515. On the one hand, this fact shows the inconsistency of the censorship; on the other hand, it points out to a skillful handling of the mimicry of the titles. It is impossible to say whether the poet changed the title due to inner motives or whether the change was intended to mislead "the controllers." A few years earlier, in the volume Izbrani stihotvorenia (1966), the poem was published under the title Bratislava 1933. 


\section{A Manuscript in the Father's Archive: From Leo Tolstoy to Edmond Fleg}

After the death of her father, Dora Gabe found a paper in his archive, the authorship of which is credited to Leo Tolstoy. The text is entitled "What Is a Jew?" and it was published in translation by the poet in Issue 3 of the Maccabi newspaper, dated $1930 .{ }^{15}$ The editor of the newspaper provided the following background about the article:

Now, however, we have the opportunity to publish an article thus far unknown by Leo Tolstoy, which, we believe, will contribute much not only to clear the disputes surrounding Tolstoy's antisemitism and philosemitism but even will cause their eventual settlement. This article was provided to us by Mrs. Dora Gabe, who found it in her late father's archive, the renowned public figure Mr. P. Gabe. The handwritten manuscript is an old, aged piece of paper, written not less than 30-40 years ago. The handwriting is unknown; it can be assumed it belonged to S. Frug, who was a close friend of Mr. P. Gabe. This we cannot claim with certainty. Perhaps, when it is possible to establish the origin of the handwriting on the paper, it will become clear how the article ended up in the papers of Mr. P. Gabe, as well as where it was taken from and written out. The very style of the article, however, can hardly supply grounds for doubting the authorship of the piece. As far as we are aware, this article has not been published anywhere in the press and anywhere in the disputes surrounding Tolstoy. It is even not included in the ninety-volume collection of his works, which the Soviet government issued on the occasion of the centennial anniversary of Tolstoy's birth and which is so full that it contains even notes from his washerwoman. How this article remained unpublished and how it landed in Mr. P. Gabe's archive is yet to be established. We are just glad that we have the fortune to be the first to give it publicity while expressing our gratitude to Dora Gabe for the manuscript which she handed to us as well as for her translation. ${ }^{16}$

In response to its antisemitic content, ${ }^{17}$ the manuscript lists Jews' contributions to the development of values such as equality, tolerance for other

${ }^{15}$ Lev Nikolaevich Tolstoy, “Kakvo e evreinat?”, trans. Dora Gabe, Maccabi 3 (1930), $4-5$.

16 "Edna neizvestna statia na Tolstoia za evreite," Maccabi 3 (1930), 4. Tolstoy's essay dates back to 1891 and its first translation was printed in London in 1908 in Jewish World.

${ }^{17}$ Some of these ideas are well known to Bulgarian readers because they have been spread since the beginning of the twentieth century. The edge of the antisemitic propaganda brochures is directed against the so-called economic superiority of the Jews living in Bulgaria, who-in the words of Stefan Tsankov- "take the shirt off of the poor peasant's back." See Stefan Tsankov, Predpazlivost ot evreyskata eksploatatsia (Shumen, 1898), 14. A part of these antisemitic clichés are imprinted on the folk memory as proverbs and sayings: "When a Jew goes ploughing, then shall they pop off," "A Jew is delighted when he sends away his son in the black, to make first of all good bargains," "His heart a kike's charshia-full 
faiths, and ethical relations regardless of people's ethnic and religious connections. The Jews are described as a God-chosen people guarding the Law of Moses-a source of faith for all monotheistic religions. A people who do not tolerate slavery, who protect equality, who treat education with deep respect, who abolished the death penalty; a people who do not seek revenge for the many humiliations to which they were subjected and who treat with great respect the representatives of other religious and ethnic identities. A people who follow the Mosaic command to "love the stranger, because you were strangers in the land of Egypt." ${ }^{18}$ The positive image of the Jews is summarized as follows:

The Jew-this is Prometheus, who took fire from the heavens and put it at the world's disposal. ... The Jew-this is an emblem of eternity - the one, whom neither sword, nor fire, nor stakes did push out of earth, who was not exterminated by millennial tortures, who first discovered the idea of God as One, kept [it] for a long period and then made it available to the whole world. The Jew-was and is, [and] will be an eternal champion and propagator of freedom, equality, civilization, and religious tolerance! ${ }^{19}$

It is interesting that this item repeats some of Fleg's foundational conceptions, as found in his essay Pourquoi je suis Juif [Why I Am a Jew], ${ }^{20}$ published in 1928 and translated into Bulgarian just one year later. ${ }^{21}$ Gabe, in her paper "Rasovi cherti na evreite v literaturata: Moysey" [Racial Traits of Jews in Literature: Moses] $]^{22}$ (1933), returns to these ideas, not only recreating some of them but also reproducing the antithetic ideas in Tolstoy's essay. In addition-as can be seen from the subtitle to her text-the most important Old Testament prophet is at the center of her

with all sorts of inconvenient thoughts." See Nadia Velcheva, "Etno-kulturen identitet na evreite v Bulgaria: Istoriko-etnografski aspekti," Jews and Slavs 15 (2005), 9-38.

${ }_{18}$ Tolstoy, "Kakvo e evreinat?", 5. The original quotation reads in the English translation: "Thou shalt neither vex a stranger, nor oppress him: for ye were strangers in the land of Egypt," Exodus 22:21, here and elsewhere in the text the translations of Bible verses are taken from the King James Bible available online at https://www.kingjamesbibleonline.org/ l.a.

${ }_{19}$ Tolstoy, "Kakvo e evreinat?", 4-5. This paragraph seems not to be included in the very few English translations of Tolstoy's article available online.

${ }^{20}$ Edmond Fleg, Pourquoi je suis Juif (Paris, 1928).

${ }^{21}$ Edmond Fleg, Zashto sam evrein, trans. Vasil Stefkov (Sofia, 1929).The publisherthe Jewish "Amishpar" Printhouse-took care to issue the paper with a forward by the author. The translator, at his end, added a brief literary profile of Fleg. It is interesting to note that Boyan Penev and Dora Gabe knew well the translations of Vasil Stefkov. In Penev's private library there is an edition of Camille Mockler's book Za platskata lyubov, translated by Stefkov and accompanied by a forward chapter by Ivan Andreychin.

${ }^{22}$ Dora Gabe, "Rasovi cherti na evreite v literaturata: Moysey," in Evrei v istoriyata, literaturata, politikata (Sofia, 1933), 47-50. 
poetic imagery, suggesting that she was already working on translating the fictionalized biography of Moses, printed in Bulgarian in 1937.23

Additional evidence confirming the poet's interest in Fleg's work is her translation of fragments from La vie de Moïse [The Life of Moses], published just months after the printing of the original book. ${ }^{24}$ Gabe's quick response in terms of a translation of the book as well as her readiness to bring the whole effort to a successful conclusion - that is, to publish the full translation-demonstrate that as a writer and a thinker Edmond Fleg had provoked and sustained the poet's attention. The fact that she dedicated an original interpretative essay to him is indicative of the meaning which Gabe assigns to his self-identification with the Jews.

These pieces of information demonstrate that in the 1930s Gabe remained in the circles of Edmond Fleg's intellectual influence. Most likely, without the impact of her upbringing and the discussions led by and with Petar Gabe, the poet would not have been so influenced by Fleg. I now draw the readers' attention to similarities in ideas presented in Gabe's article and the autobiographical essay by the French playwright-ideas which reflect and repeat arguments that also appear in Tolstoy's manuscript, which in turn allow us to establish parallels between the texts Why I Am a Jew (Fleg), What Is a Jew? (Tolstoy), and "Racial Traits of Jews in Literature" (Gabe).

\section{Fleg and Gabe Recall Why They Are Jews}

The problem, common for all three writers, relates to the conflict between the essence of Jewish ways of sensing the world and their historical existence. According to Fleg, the most characteristic traits of Judaism and Jewishness are inherited. Each member of the community is connected through kinship to these traits. ${ }^{25}$ That is why Fleg's message is addressed to his unborn grandson. Simultaneously, however, Jewish tradition is

${ }^{23}$ Edmond Fleg, Moysey, trans. Dora Gabe (Sofia, 1937).

${ }^{24}$ Edmond Fleg, "Hanaanskiyat grozd: Otkas ot knigata 'Moysey'," trans. Dora Gabe, Maccabi 9 (1929), 2:11-13. See id., La vie de Moüse (Paris, 1928).

25 "And I said to myself: from that far distant father to my very own father, all these fathers have transmitted a truth to me, which ran in their blood, which runs in my blood; and must I not transmit it with my blood to those of my blood? Will you accept it, my child? Will you transmit it?", Edmond Fleg, Why I Am a Jew, trans. Louise Waterman Wise (New York, 1933), in The Internet Archive, https://archive.org/stream/whyiamajew028020mbp/ whyiamajew028020mbp_djvu.txt [retrieved: 16 July 2017]. 
subjected to continuous interaction with foreign cultural communities, to the degenerating influence of historical facts that threaten its consolidating functions. For example, the need for religious norms to adapt to the everyday demands of secular life has destructive meaning for the writer. ${ }^{26}$ Another substantial factor, complicating Jewish identity, is the inaccessibility of Judaic tradition - transmitted in a language incomprehensible for most Jews, it transforms itself into an anti-intellectual declamation, which competes with the clear chronology of the historical narrative of other nations. ${ }^{27}$

According to Gabe, for Jews slavery is the force that undermines their identity and self-awareness. And while their inability to subdue their laws is presented in Fleg's work as a play-script of everyday life, in the poet's work the unachievable harmony with biblical commands becomes predestination. Gabe constructs the first part of her essay around the image of the Jew whose two types of inner essence are at odds- that of the man of wisdom and that of the slave:

The Jew today maintains two profoundly contradictory characters: the old biblical one-which is immortal within him, who invisibly rules his soul and in whom his gifts are deposited, who leads him to the humane and keeps him always close to the shekhinah (the Divine Presence) - and the other character that was elaborated in him over 2000 years of slavery, in his struggle to win a place at least in the material world, [the only place] where there has been freedom. This other Jew is in a hurry to earn, and all his concerns are directed this way. ${ }^{28}$

A personification of the inner struggle of two opposites according to the poet is in the character of Samuel from Wyspiański's drama entitled

${ }^{26}$ Fleg gives an example of the moments in which those in his immediate surroundings break the religious vows that are compulsory for observing Jews. Precisely those episodes of his childhood make him increasingly critical of his ancestors' religion: "I did not write on Saturday at school. That was forbidden. But at college my elder brothers wrote on that day just as on other days; their studies made it necessary. My father went to his office on Saturday after synagogue services. He also wrote, his business made it necessary. Was, therefore, the rest on the Sabbath-day only important for very little boys?" Ibid.

27 "Thus, like all children of all time, I began despising myself to scrutinize my parents and drawing conclusions from their inconsistencies [and] I very slowly began to break with their idols. Others unconsciously became my accomplices. The first of these was my teacher of religion, the cantor of the synagogue. He had a beautiful voice, a beautiful beard, a beautiful soul. But as a teacher he puzzled me, I was at this time attending college and was proud of my Latin. Now this man taught that Hebrew had no grammar, which caused me to feel dubious about that language and what it inculcated. Then too, his method alone would have discouraged the most inquisitive of minds. I mumbled prayers which he declared untranslatable." Ibid.

${ }^{28}$ Gabe, "Rasovi cherti na evreite v literaturata," 47. 
Sędziowie [Judges], who has to fight two elements: one of pure inspiration and talent, which has possessed his little son; and the other, that of the pragmatic common sense that rules his firstborn heir, who is focused on satisfying material needs and aspirations. The poet thinks of Samuel's image as a warning against the dangers that Jewish tradition faces: "[w] hen the young son dies, the soul of his father dies-there is no longer a reason to live, there is no luminary in his soul, and without [this luminary], he is a dead man." ${ }^{29}$ Despite the historical logic, though, the essence of Jewish tradition remains. According to both Fleg and Gabe, a source of this perseverance is the kinship memory preserved in the written word. The poet's imagery gives figurative relief to the phenomenon, which the playwright calls "recalling":

Is there an ancestral memory? I can no longer doubt [such a memory] because that which I then learned seems to me not to have been learned at all but to have been remembered..$^{30}$

the one who looks in a humane way sees behind the small seller with dirty nails on his hands and untrimmed beard such an old man of wisdom who leans over a big old book and drinks from its wise sayings. ${ }^{31}$

Both authors believe that the Jewish people has preserved itself by virtue of its wisdom. Consciousness of being chosen by God is the main ingredient of this wisdom. Fleg and Gabe perceive the special role of Jews in the history of humankind not as a prize, but as self-sacrifice and a responsibility. A symbol of this responsibility, according to the poet, is Job, who "in his grief cleanses himself and ascends, instead of perishing shattered underneath the burden of his suffering." ${ }^{32}$ The fate of the Old Testament hero repeats the destiny of the Jews who expiate through their own suffering the road of humankind toward justice and peace: "The ideal of the Jewish God is to choose a people who can help humankind to rise and become free. A religion that does not care only for itself, a people that does not live only for itself." ${ }^{33}$ These words of Dora Gabe summarize the most meaningful response of Edmond Fleg to the questions, "How should I be a Jew? Why should I be a Jew?"

\footnotetext{
${ }^{29}$ Ibid., 48.

${ }^{30}$ Fleg, Why I Am a Jew.

${ }^{31}$ Gabe, "Rasovi cherti na evreite v literaturata," 47.

${ }^{32}$ Ibid., 50.

33 Ibid.
} 


\section{Toward Fleg's Definition of Jewish Identity}

For Fleg, the most important commandments which the Jew should observe are from the Old Testament: "[1]ove the Lord, thy God, and love thy fellow man as much as thyself." These two commandments are, in effect, one and the same and consolidate monotheism and messianism. As Fleg argues, linking the two commandments leads to the idea that because man is the image and likeness of God, to love your fellow man means to love God. From here, according to the writer, the mission of the Jewish people is to unite all other people around the idea of a monotheistic deity and to arrive at a universal agreement, grounded in the belief that with the coming of the Messiah peace and calm will settle, because the division between human beings offends the divine unity. These convictions of Fleg, shared by Gabe, are supported by his ecumenism and his attempt to build a bridge between Judaism and Christianity.

Fleg's views were formed under the influence of several key historical events, which led to the cultural blossoming of the Jewish community in France in the 1920s. After Jews acquired full civil rights at the end of the eighteenth century, they also gained the opportunity to participate in French public, political, and cultural life on an equal footing with other ethnic groups. On the one hand, the time saw the beginning of the Jews' emancipation. On the other hand, a long-term process of expanding the meaning of the concept of "a Frenchman" began, a concept which gradually opened up new forms of identification. The marriage of acquired political, economic, and cultural equality to the ideals of the French Revolution led in certain Jewish circles during the nineteenth century to equating the basic principles of Judaism with the liberal values of tolerance, freedom, and equality.

On the religious plane the development of the Jewish community also changed significantly. Separation of church and state powers, sanctioned by law in 1905, which postulated that public institutions be neutral regarding faith, led to religious pluralism and to creating new Jewish religious public organizations. Under the influence of the accelerating trends of secularization the Jewish intellectuals formulated so-called cultural Judaism, in the framework of which Jewishness transformed into a cultural identity based on shared tradition and history.

At the same time, Fleg bore witness to the Dreyfus trial. The Dreyfus Affair became a catalyst for his ethnic and religious self-identifi- 
cation. ${ }^{34}$ The antisemitic moods, awoken during the court proceedings against Alfred Dreyfus, provoked the writer to turn to Zionist ideas. These concepts defined the transformation of the religious and ethnic consciousness into a national one, crucial to the future of the Jewish people. ${ }^{35}$ This view was particularly strong during the 1899 Third Zionist Congress, which Fleg attended. Drawing on the experience acquired during his student years at elite French universities; being an established and central figure in the "Aesthetes" literary circle; harvesting success as a playwright-in short, embodying the Jewish cultural prosperity of the 1920s-Fleg vividly reacted to the antisemitism that grew at the time not only in France but in all of Europe.

Experiencing strong internal conflict, the writer dedicated himself to the study of Judaism. All of his later creative labor is connected to two of his ideas, formed under the influence of the conflicting tendencies that he attempted to reconcile. The first idea was his original view on universal human spirituality regardless of which religion one practiced.

${ }^{34}$ See Aron Rodrigue, "Rearticulations of French Jewish Identities after the Dreyfus Affair," Jewish Social Studies 2 (1996), 3:1-24.

${ }^{35}$ Edmond Fleg and Dora Gabe gave a testimony to the process of becoming aware of their ethnic identity in identical ways. For both writers a key moment was the explosion of antisemitic moods in French and Bulgarian society respectively. For Fleg the catalyst was the proceedings against officer Dreyfus; and for Gabe it was the court proceedings against her as an author of a teaching primer. As the poet says: "Until the legal case happened, the thought has never crossed my mind that I am of different descent;" see Ivan Sarandev, Dora Gabe: Literaturni anketi (Sofia, 1986), 85. The clash with these phenomena forced them both to give an account to themselves that there has always been, secretly hiding in their minds, a fear of massacres and persecutions-a fear, transferred from a generation to generation. The news about the Dreyfus Affair brought to Fleg's mind the stories told by his mother: "Greedy, sensual, a thief and forger, the Jew was a traitor by choice and by his very nature, and if Dreyfus needed a motive for his crime the one fact that he was a Jew explained his treason.... I did not recognize myself in this portrait of the Jew. I was quite sure I was not planning any sinister project by which the world might be overwhelmed. Without feeling myself affected, I was nevertheless unnerved. This antisemitism was a new experience to me. When very young I had heard tell of course of the massacres of Jews in Russia which followed the assassination of a Czar; of women disemboweled, of old men buried alive, nursing babies plunged into petroleum and then thrown to the flames. For a time these memories had haunted my nights" (Fleg, Why I Am a Jew). Dora Gabe, at her end, recalls the nightmare dream of her own mother, Ekaterina Samoylovna Duel: "A hungry little Jew kneels down in front of a blackened morsel of bread in the mud on the pavement. There is a boot rising above the little hand that reaches out [to the morsel]. [The boot is] shining, huge. A second passes and ... [there is] a plaintive scream, a cynic giggle and guilty passers-by who loosely slide their gaze through the shop windows. And the child runs towards the hunger brothels. Fear, a mindless fear, runs after him" (Mihail, Tazhnite ochi na minaloto, 91). The antisemitism in Bulgarian and French society forced both artists to confront the reality which sub-consciously they had already been foreseeing. 
This spirituality is evidence that representatives of different faiths not only have to collaborate with each other but that they also must comprehend the interrelatedness of their religious beliefs. The second idea is connected to trust in the possibilities for dialogue between Jews and Christians - a dialogue which has to be based on mutual tolerance.

That is why, when Sally Charnow explores Fleg's ecumenic sensitivity, a sensitivity developed during World War I and was embodied in the aims and values propagated in l'Union sacrée, she thinks that it is more appropriate not to consider Fleg's work as a labor of a Jewish writer:

[i]t may be useful to see his work in the broader context of the traumatized French post-war society and its Catholic renewal. . . . Along with Charles Péguy and Jacques Maritain, Fleg aimed to offer the "rational" intellectual access to a new kind of mystic-realism in which the temporal and eternal dimensions of human existence were not positioned in opposition to one another but existed on a continuum. For Fleg, this continuity allowed him to envision a future in which Christians and Jews inhabited a "new Jerusalem" based on universal humanistic values. ${ }^{36}$

Yaniv Hagbi believes that Fleg was not a religious Jew in the traditional sense of this concept, but that he was definitely a religious intellectual because he consciously constructed a body of texts that corresponded to his beliefs and convictions and which formed a universal understanding of Judaism. ${ }^{37}$ Summarizing these characteristics of the French writer-his unorthodox faith, his difficulty to define nationality, and his openness to dialogue-Lawrence Hoffman concludes that Fleg defined Jewish identity as a moral space. ${ }^{38}$

\section{Gabe as an Interpreter of Fleg's Ideas}

Fleg offers a synthesized image of his views in Moses' fictionalized biography. The Old Testament prophet entertained the writer's imagination for several decades. Moses is a key figure to Fleg's thinking because Moses brought together Fleg's ideas about the universalities of Judaism, about

${ }^{36}$ Sally Charnow, "Imagining a New Jerusalem: Edmond Fleg and Inter-War French Ecumenism," French History 27 (2013), 4:557-578.

37 Yaniv Hagbi, "The Book of Edmond: Manifestations of Edmond Fleg's Worldview in His L'Anthologie Juive," in Hillel Weiss, Ber Kotlerman, Roman Katsman (eds.), Around the Point: Studies in Jewish Literature and Culture in Multiple Languages (Cambridge, 2014), 213-230.

${ }^{38}$ Lawrence A. Hoffman, "Principal, Story, and Myth in the Liturgical Search for Identity," A Journal of Bible and Theology 64 (2010), 3:231-244. 
the messianic mission of the Jewish people, and about the interweaving qualities of Old Testament beliefs and the Gospel. In The Life of Moses, Fleg highlighted these moments from the Jews' exodus from Egypt and from the Sinai Covenant to assert his own convictions. Some of these narratives are spread through oral Jewish tradition and are included in the Talmud and the Midrash. Such is the episode in which before giving the Torah to Moses, God gives it to Esau, Moab, the sons of Ishmael, and only then to other peoples. With the vivid narration about their refusal to accept the Pentateuch, the writer emphasizes that before being the God of Israel, the Eternal One is the God of all people and that the mission adopted by the Israelites is an extremely burdensome one-which is why this mission is faced with a lack of understanding. According to Fleg's interpretation, when Moses convinces the Jews to adopt the Torah he suggests to them that this is not a privilege, but an adoption of a service:

Difficult is the beginning of everything, but most difficult of all is being humble and the beginning of it; but you began to be meek and the one who is humble in the sorrow soon finds humility in joy too; and so to be meek before the Lord is the greatest joy. Your eyes saw what miracles he did for you when he set you free from Egypt, from hunger and from thirst. However, you have not yet received his Torah. And what miracles would he not do when you receive it and listen to it, and follow it. ... But when the Torah belongs to you, you will belong to the Torah. ${ }^{39}$

In his autobiographical essay Why I Am a Jew, Fleg pays special attention to the consistency between the Law of Moses and the Divine Word announced by Jesus: "Thou shalt love the Eternal thy God, with all thy heart, with all thy soul, and with all thy might.' This utterance quoted by Jesus was first spoken by Moses." ${ }^{40}$ This re-interpretation of verses from Deuteronomy (10:12, 11:13, 30:6: "to love the Lord thy God with all thine heart, and with all thy soul, that thou mayest live") and Leviticus (19:18: "thou shalt love thy neighbor as thyself") serves as a motto of the anthology entitled L'Anthologie Juive, edited and published by Fleg in 1923. For him, these two commandments synthesize the meaning of Judaism. These commandments are attributed to Moses but also play a particularly important role in the New Testament. In citing them, Fleg actually shows the proximity of the two religions. According to him, these

\footnotetext{
39 Fleg, Moysey, 23.

${ }^{40}$ Fleg, Why I Am a Jew.
} 
two imperatives, which are the essence of both Judaism and Christianity, are at the basis of all spirituality. ${ }^{41}$

Gabe interprets the image of Moses in a similar fashion, also perceiving the descendant of Leviticus as a key figure in the Old Testament. She regards him as a personification of Jews' best features:

All peoples have created one archetype, be it carried in a man of wisdom or in a poet, in a hero or in a prophet. They have deposited [in this archetype] all elements of their race so as to keep them inside this treasury and so that [they] have in front of them a model from which they may not divert. Such is the image of Moses for the Jews. ${ }^{42}$

According to the poet, Fleg precisely presents the prophet accurately, emphasizing Moses' human qualities. The prophet, like all humans, experiences anger, doubt, and despair: "[h]e is not that naked abstraction, that deity which never descends from its heaven," ${ }^{43}$ Gabe summarizes. That is why the image, created by Fleg, according to her, is genuine.

Another feature in Fleg's narrative about Moses which made an impression on Gabe is his "love and grief" for his people. He was the good counselor, educator, and mentor who patiently led "his 600,000 children" out of slavery and out of their slave customs. Similarly, the Old Testament God is presented as follows: "The biblical God in Fleg's book-Gabe comments-is merciful and full of love towards Moses and through himtowards his people." ${ }^{44}$ It is evident from the poet's comment that Fleg's notion of the closeness between Jewish and Christian traditions had an impact on her. The image of the merciful Lord who relates to his subjects with fatherly love prefigures the New Testament figure of the God-Father, who sends his son to expiate the sins of humans. According to Gabe, Moses, as seen through Fleg's eyes, is a prototype of the theanthropic god, a prototype of Christ:

In [Fleg's work] Moses and God sometimes blend in one image. Moses becomes divine and God [becomes] human. God gives birth to the idea of the salvation of all the people-Moses [gives birth to] the idea of the spiritual and moral salvation of the Israelite people. This idea about the reincarnation and purification of the people through sufferance and tempering in a struggle with the help of God, who leads with a steady hand and a merciful heart, is perhaps the most beautiful and

\footnotetext{
${ }^{41}$ See Hagbi, "The Book of Edmond," 222-223.

${ }^{42}$ Gabe, "Rasovi cherti na evreite v literaturata," 48.

${ }^{43}$ Ibid.

${ }^{44}$ Ibid., 49.
} 
the greatest idea borne by the past of Jewishness. Because it is for all the times and all the people who have been through slavery. ${ }^{45}$

Further in her interpretation, which to this point corresponds to the views of the French writer and the ways in which he perceives the world, Gabe turns toward the future, expressing her own position. The composition of her text goes back to the founding - in her viewpoint-image of the Jew-slave and the Jew-wiseman, and the Old Testament prophet is positioned as a model for contemporary times:

The leaders, who prepare the youth for the Promised Land, should not forget their prototypical image-Moses-[so that they] can penetrate, like him, into the character of their people, to discover and to trample on the slave's traits in this people, to peel off that bark, acquired in slavery, which has hidden his spirit. So that those flaws are brought out [into the open], become susceptible to awareness and are undermined. And when the grapes of the Promised Land ripen and [the Land] calls upon its people, let there be a generation that deserves to come back [to the Land]-let [this generation] be not a foreigner who came there, but as if it is [the Land's] own son, long known [to the Land] and long waited for. ${ }^{46}$

Thus, central to Gabe's text remain the image of slavery, which Jews have to overcome, and of Moses-as a highly ethical and moral exemplar-who is an embodiment of the qualities needed to reconstruct the slave, to transform each of them into a human, who is free, just, wise, full of compassion and love toward his fellows. The humanistic ideas of Fleg, synthesized in the fictionalized biography of the Old Testament prophet, are, according to Gabe, necessary for the Jewish people, especially in their present moment "because the longest [slavery], a 2,000-year-old one, is the present slavery of Israel." ${ }^{47}$ The poet's interpretation subdues the work of the French writer to the goals of Zionism.

\section{Feminist Entanglement of Gabe's Zionistic Inclinations}

I shall now return to the contradiction mentioned at the beginning of this paper. Taking into account Gabe's engagement with Zionism as expressed in her work for the Maccabi newspaper, ${ }^{48}$ in the popularization of the

${ }^{45}$ Ibid., 50.

${ }^{46}$ Ibid.

47 Ibid.

48 The Maccabi newspaper is an organ of the Maccabi Union of the Zionist Athletic Clubs in Bulgaria. The purpose of these clubs, which date back to 1897, is to popularize 
work and ideas of Edmond Fleg, and in extracting contemporary political content from his readings of biblical texts, what drove those publishing in the journal to criticize her life choices? Particular disapproval was raised about Gabe's detachment from Jewish circles, a detachment connected to her baptism and her active creative work. ${ }^{49}$ Her public activism, her success as chair of the Bulgarian PEN Club, her activism as a member of the "Dobrudzha" Union-all were perceived as signs of her full assimilation into the Bulgarian public and cultural scene and were assessed negatively because - as Ben Avram argued - "assimilation as a road to solving the Jewish question proves to be inefficient, even destructive for the Jewish people." ${ }^{50}$ The author did not leave space for a multi-cultural belonging and for multiple national identifications. According to him, the main reason that drove Jews to assimilate was mercenary. Thus, the poet was indirectly accused of "avarice" and "vanity," of neglecting the struggles of her own people so that she could lead a happier, meaningful, and-more important-free life.

These convictions synchronized with ideas about the Jewish woman propagated in the pages of the journal. According to Leon Farhi, the

gymnastics and sports among young Jews. This is the only Jewish organization which propagates sports and bodily education among Jewish youth. Alongside the organization of competitions, tournaments, and training, the Maccabi clubs organize excursions, talks, and dancing-parties. In parallel with bodily education the clubs aim at seeding a national spirit and a sense of solidarity among young Jews. The Union's chronicle, which describes in detail Maccabi's relations with the Zionist Organization, to which its members move after turning 18 years old, explains that the role of the Maccabees for the national movement of the Jews was particularly important: "It [the organization] has served, throughout approximately three decades, as a school to the nurturing of Jewish youth in a strong national spirit. It created a constellation of dedicated champions, who made and continue to give dear sacrifices for the celebration of the Zionist ideal." See Belezhki za istoriyata na sayuza "Maccabi" $v$ Bulgaria (Sofia, 1930), 57. Cf. the broad-scope pieces of information about the Jewish organizations in Bulgaria until the end of World War II, in: David Koen, "Balgarskite evrei - sotsialen zhivot (1878-1947)," in id., Evreite v Bulgaria 1878-1949 (Sofia, 2008), 105-174. For more information about the newspaper Maccabi see Katia Baklova, "Maccabi (1920-1940)," in Elka Traykova, Vihren Chelnokozhev (eds.), Periodika i literatura: Literaturni spisania i vestnitsi, smeseni spisania, humoristichni izdania (1918-1920) (Sofia, 1999), 5:383-392.

49 "This suffering soul wanted to tear down all the chains - the chains of kinship, of maternity and of earthly pleasures. But no peace it is finding and more and more torn painfully it is. Following her graduation from the gymnasium in Varna, Dora Gabe goes abroad. She spends her student years away from her parents. She also starts her departure from the people to which she belonged up until this moment and to which her old mother belongs until the present day. Perhaps under the influence of the environment or may be in order to break down the "chains' that stay on her way to improvement and popularization." See Mayer, "Dora Gabe: Etyud," 11, 13.

50 Avram, "Gorchivata chasha," 5. 
contemporary Jewish woman should uphold canonic Jewish traditions and values because "the woman is an inborn representative and a keeper of the national heritage." In the talk, published in Maccabi under the title "Drevnata i moderna evreyka" [The Ancient and Modern Jewish Woman $]{ }^{51}$ he pays special attention to the difficult situation in which every woman who has to choose between the assimilationist leanings coming from the external environment and the centripetal forces of traditional cultural values finds herself. According to Farhi, the inclusion of Jewish women in the culture of the nation in which they live does not lead them to self-improvement and self-assertion:

[The modern Jewish woman] follows the instructions and ways of non-Jewish women-in the good and the bad, forgetting the high virtues of her great-grandmothers. Today she feels flattered, if Christian women think that she behaves, thinks, and looks like a Christian. As if each difference existing between a Jewish and a non-Jewish woman should be destroyed in the interest of the misunderstood cultivation. ${ }^{52}$

According to Farhi, Christian culture, into which Jewish women blend, does not give them the opportunity to develop their natural abilities but encourages them to pay more attention to their appearance, to those arts that present them best in society (such as singing, dancing, playing piano) and to material goods. Jewish women who allow themselves to assimilate forget the true wisdom hidden in the holy books:

As the centuries flowed, the mind of the Jew had sharpened thanks to study of the Talmud. Studying the Talmud, like no other tension of the mind, sharpens abruptly the mental abilities for speculation and philosophy in particular. The father leaves as a heritage to his children these abilities of his too. In such a way, as the centuries flow, the mind of the Jewish woman and especially her ability for philosophical reasoning developed sharply. Despite such a legacy of richness of the soul, the Jewish woman today leans not towards deep philosophical thought, but towards life's superficialities. ${ }^{53}$

The idea that the woman has to develop her skills and to self-improve does not displace her traditional roles of a wife and a mother. As Farhi argues, "the Jewish woman's striving toward marriage is much stronger than it is in the non-Jewish woman" and "Jews consider childlessness

${ }^{51}$ Leon Farhi, "Drevnata i moderna evreyka," Maccabi 7-10 (1931), 6-13, 9-13, 8-12, $8-16$, respectively.

${ }_{52}$ Farhi, "Drevnata i moderna evreyka," Maccabi 10 (1931), 9-10.

${ }^{53}$ Ibid., 10. 
a curse and a divine punishment. Infertile women are expelled and despised by their husbands." 54

Against the background of these convictions it is obvious that the emancipated social and political behavior of Gabe provoked the objections of Sammy Mayer and Ben Avram. To that behavior, however, as an especially serious occasion for their dissatisfaction, the original perception of the poet regarding Zionism has to be added. Her view is untraditional and, to some extent, paradoxical because it excludes any form of nationalism. The exposé to "Racial Traits of Jews in the Literature: Moses" shows that, for the poet, the leaders of the Zionist movement have to serve as a moral corrector to the people, and the national state established in the Promised Land should represent the moral emanation of this people. Gabe identifies the Zionist movement, first of all, with adherence to certain Jewish ethical and cultural values. For her, the national belonging of the Zionists comes second. Moreover, according to the poet-and Fleg's influence here is obvious-participation in Zionist initiatives does not limit the national self-identification of Jews from the Diaspora who have the right to more than one fatherland. In the words of Fleg: " $[\mathrm{t}]$ he Zionist program in no way implied the return of all Jews to Palestine-a thing numerically impossible, for the Jewish country only offers itself to those Jews who feel that they have no other country." ${ }^{55}$

This original interpretation of Zionist ideas allows us to understand the parallels between the contributions of Edmond Fleg on one hand, and Dora Gabe on the other. The writer identifies himself as a Jew and a Frenchman: "I felt that I was a Jew, essentially a Jew, but I also felt myself French, a Frenchman of Geneva, but French." The poet-as a Jewish woman and a Bulgarian woman: "I have never thought that it is disgraceful, the way others thought, that one is of a different descent, especially Jewish. I knew how many great people Jewishness has given [to the world] and what martyrdom is this persecution, but I was too much of a Bulgarian woman." 56

The poet's multi-level and multi-cultural identification, open to religious ecumenism and to ideas of women's emancipation, encounters misunderstanding and misreadings. Because it is hard to define, it is problematic for all those—whether of Bulgarian or Jewish origin —who

\footnotetext{
54 Ibid., 12, 13.

55 Fleg, Why I Am a Jew.

56 Sarandev, Dora Gabe, 85.
} 
look for firm criteria of national or ethnic belonging. In Dora Gabe's case, taking into account her original ideas on Zionism and her controversial relations with Jewish circles in Sofia before World War II, stating that she is a Bulgarian Jew or a Jewish Bulgarian is never enough. When interested in the complex problem of her identity, one needs to pay attention to the interrelatedness, tensions, and dynamics between these categories. In fact, the most important topic — as I tried to argue here-concerns the intersections between the poet's multiple identifications.

Adriana Kovacheva Adam Mickiewicz University in Poznań anikovacheva@gmail.com 